\title{
Anaerobic bacterial degradation of protein and lipid macromolecules in subarctic marine sediment
}

\author{
Claus Pelikan ${ }^{1,2} \cdot$ Kenneth Wasmund $\mathbb{1}^{1,2} \cdot$ Clemens Glombitza ${ }^{3,4} \cdot$ Bela Hausmann $\mathbb{1}^{1,5,6} \cdot$ Craig W. Herbold $^{1} \cdot$ \\ Mathias Flieder ${ }^{1}$. Alexander Loy $\mathbb{B}^{1,2,5}$
}

Received: 25 April 2020 / Revised: 13 October 2020 / Accepted: 19 October 2020 / Published online: 18 November 2020

(c) The Author(s) 2020. This article is published with open access

\begin{abstract}
Microorganisms in marine sediments play major roles in marine biogeochemical cycles by mineralizing substantial quantities of organic matter from decaying cells. Proteins and lipids are abundant components of necromass, yet the taxonomic identities of microorganisms that actively degrade them remain poorly resolved. Here, we revealed identities, trophic interactions, and genomic features of bacteria that degraded ${ }^{13} \mathrm{C}$-labeled proteins and lipids in cold anoxic microcosms containing sulfidic subarctic marine sediment. Supplemented proteins and lipids were rapidly fermented to various volatile fatty acids within 5 days. DNA-stable isotope probing (SIP) suggested Psychrilyobacter atlanticus was an important primary degrader of proteins, and Psychromonas members were important primary degraders of both proteins and lipids. Closely related Psychromonas populations, as represented by distinct 16S rRNA gene variants, differentially utilized either proteins or lipids. DNA-SIP also showed ${ }^{13} \mathrm{C}$-labeling of various Deltaproteobacteria within 10 days, indicating trophic transfer of carbon to putative sulfate-reducers. Metagenome-assembled genomes revealed the primary hydrolyzers encoded secreted peptidases or lipases, and enzymes for catabolism of protein or lipid degradation products. Psychromonas species are prevalent in diverse marine sediments, suggesting they are important players in organic carbon processing in situ. Together, this study provides new insights into the identities, functions, and genomes of bacteria that actively degrade abundant necromass macromolecules in the seafloor.
\end{abstract}

These authors contributed equally: Claus Pelikan, Kenneth Wasmund

Supplementary information The online version of this article (https:// doi.org/10.1038/s41396-020-00817-6) contains supplementary material, which is available to authorized users.

Kenneth Wasmund

kenneth.wasmund@univie.ac.at

$\triangle$ Alexander Loy

alexander.loy@univie.ac.at

1 Division of Microbial Ecology, Centre for Microbiology and Environmental Systems Science, University of Vienna, Vienna, Austria

2 Austrian Polar Research Institute, Vienna, Austria

3 Department of Biology, Center for Geomicrobiology, Aarhus University, Aarhus, Denmark

4 Department of Environmental Systems Science, ETH Zürich, Zürich, Switzerland

5 Joint Microbiome Facility of the Medical University of Vienna and the University of Vienna, Vienna, Austria

6 Department of Laboratory Medicine, Medical University of Vienna, Vienna, Austria

\section{Introduction}

The majority of marine sediments that underlie the Earth's oceans are dominated by heterotrophic microorganisms, which are primarily sustained by "pelagic-benthic" coupling [1]. This is driven by a constant supply of organic matter from planktonic organisms that thrive in the overlying water column and settle with particulate aggregates to the seafloor after their death [2]. The amount and composition of organic matter that reaches the seafloor is strongly dependent on water depth, whereby continental shelves and shallow sediments generally receive greater inputs compared to deep-sea sediments [3]. In cold polar regions with lower microbial activities in the water column [4], a large fraction of the phytodetritus from spring bloom-like events reaches the underlying sediments [5]. Additionally, organic matter can originate from autochthonous microbial production [6] and from land-derived sources, which can be substantial in areas close to land and rivers, as well as polar regions subjected to melting $[2,7]$. 
Organic matter in marine sediments is composed of an immense diversity of macromolecules, of which a substantial fraction can be enzymatically degraded and utilized as nutrient and energy sources by microorganisms [2]. Proteins and lipids typically constitute $10 \%$ and $5-10 \%$ of the organic matter found in marine sediments, respectively $[8,9]$. Proteins, peptides, and amino acids are important sources of nitrogen [10], particularly in sediment habitats containing limited amounts of inorganic nitrogen sources [11]. Lipids generally consist of an alkyl chain that is esteror ether-bound to a polar head group such as phosphoglycerol, or a glycerol that is glycosidically bound to a sugar moiety. They are major components of phytoplankton biomass [12, 13], of which the less labile fraction survives degradation in the water column [14] and is degraded by microorganisms in the underlying sediments [15]. Longchain fatty acids released from lipid hydrolysis are energyrich compounds [16], and can be expected to be favorable substrates for microorganisms.

Most macromolecules are too large to be directly imported into cells and must therefore be degraded, at least partially, outside the cells [17]. Hydrolysis of macromolecules via the activity of extracellular enzymes secreted by microorganisms is the rate limiting step during organic matter mineralization in marine sediments [17, 18]. Microorganisms utilize a compositionally and functionally large diversity of extracellular hydrolases to facilitate the extracellular breakdown of macromolecules [19]. For example, peptidases in sediments of Arctic fjords in Svalbard had greater substrate ranges for different peptides and much higher activities (tens to hundreds of thousands nmol $\mathrm{l}^{-1} \mathrm{~h}^{-1}$ ) than peptidases in the water column [20]. This showed that sediments act as important biogeochemical hotspots for processing organic macromolecules. Interestingly, peptidase activity was negatively correlated to amounts of phytodetritus inputs, whereas lipase activity was positively correlated [11]. This indicated that peptidases are excreted in times of nutrient limitation, whereas lipases are excreted when organic matter availability is high [11].

The microbial degradation of organic macromolecules in anoxic marine sediments is a complex inter-species process involving "primary degraders" that break down larger macromolecules into oligomers and monomers for fermentation to alcohols, lactate, and/or short-chain volatile fatty acids (VFAs), which are then mineralized to $\mathrm{CH}_{4}, \mathrm{CO}_{2}$ and/or $\mathrm{H}_{2}$ [21]. "Terminal oxidizers" of fermentation products prevalent in marine sediments, such as sulfatereducing microorganisms (SRM), have been relatively well studied [22-27]. On the other hand, the key microbial players responsible for the primary hydrolysis of different types of organic matter and macromolecules are poorly understood. Most studies are based on predictions from genomic analyses [28-31], whereas experimental evidence linking identities to functions are lacking.

In the present study, we investigated the identities, genomic features, and ecological interactions of bacterial taxa that may play important roles in protein and lipid macromolecule degradation in subarctic marine sediments. We performed laboratory experiments whereby sulfidic arctic marine sediments were incubated in microcosms under cold $\left(4^{\circ} \mathrm{C}\right)$, anoxic conditions, and supplemented with either ${ }^{13} \mathrm{C}$-labeled proteins or ${ }^{13} \mathrm{C}$-labeled lipids. Incubations were performed at $4{ }^{\circ} \mathrm{C}$ to simulate temperature conditions of deep marine waters and seafloor, which are permanently cold [32]. These microcosms were also incubated under conditions where sulfate reduction was specifically inhibited, in order to elucidate the roles of SRM. Catabolism and assimilation of ${ }^{13} \mathrm{C}$-labeled substrates by the sediment bacteria were investigated by DNA-based stable isotope probing (DNA-SIP) and amplicon sequencing of $16 \mathrm{~S}$ rRNA genes. The degradation of organic matter was monitored by measuring concentrations of VFAs and sulfate. Genome-resolved metagenomic analyses were used to predict secreted hydrolytic enzymes and reconstruct organic matter degradation pathways encoded by the taxa identified by DNA-SIP. This revealed (1) the identities and foraging strategies of several key protein- and lipid-consuming bacteria in marine sediments, (2) that niche partitioning among Psychromonas subspecies was based on differential utilization of proteins and lipids, and (3) that SRM of the family Desulfobacteraceae mainly utilized the macromolecule degradation intermediates, i.e., VFAs.

\section{Materials and methods}

\section{Sediment incubations}

Sediment slurries were produced with sediment obtained from intact Rumohr cores (0-30 cm below seafloor) from Greenland (Nuuk fjord "station 3," water depth $498 \mathrm{~m}$, August 2013, 64 $26^{\prime} 45^{\prime \prime} \mathrm{N}, 52^{\circ} 47^{\prime} 39^{\prime \prime} \mathrm{W}$ ) [33], mixed 1:1 (v/v) with anoxic artificial seawater [34] containing $\sim 28 \mathrm{mM}$ sulfate. Intact sediments were stored for $\sim 5$ weeks at $4{ }^{\circ} \mathrm{C}$ prior to the incubations. For each microcosm, $40 \mathrm{ml}$ of this slurry was distributed into $250 \mathrm{ml}$ serum vials under anoxic conditions in an anoxic glovebox (nitrogen atmosphere containing $2 \%$ hydrogen and $10 \% \mathrm{CO}_{2}$ ). Microcosms were sealed with thick butyl rubber stoppers and crimped, and flushed with $\mathrm{N}_{2}$ after removing from the anoxic glovebox. All subsequent subsampling was also performed within the anoxic glovebox, with microcosms placed on ice packs to minimize warming of incubations. Triplicate microcosms were either supplemented with a single dose of: (1) $300 \mu \mathrm{g} \mathrm{C} \mathrm{g}{ }^{-113} \mathrm{C}$-labeled Algal lipid mixture-99 atom $\%{ }^{13} \mathrm{C}$ (ISOTEC, Sigma-Aldrich); (2) $300 \mu \mathrm{g}$ 
$\mathrm{C} \mathrm{g}^{-1}{ }^{13} \mathrm{C}$-labeled Algal crude protein extract-98 atom\% ${ }^{13} \mathrm{C}$ (ISOTEC, Sigma-Aldrich), (3) $300 \mu \mathrm{g} \mathrm{C} \mathrm{g}{ }^{-1}{ }^{13} \mathrm{C}$-labeled Algal lipid mixture (as above) and the sulfate reduction inhibitor molybdate (28 mM; [35]); (5) $300 \mu \mathrm{g} \mathrm{C} \mathrm{g}^{-1}{ }^{13} \mathrm{C}$ labeled Algal protein mixture (as above) and molybdate $(28 \mathrm{mM})$; or (6) were left without supplementation (no-substrate controls). Concentrations of substrates added to microcosms were chosen on the basis of previous research that showed bioavailable (hydrolysable) proteins up to $335 \mu \mathrm{g} \mathrm{g}^{-1}$ of deep-sea surface sediments [36]. Although no information for bioavailable lipids in sediments was available, we considered that they may be in a similar range because concentrations of total lipids and proteins are typically within similar ranges (at least within the same order of magnitude) in various sediments [37]. The microcosms were incubated at $4{ }^{\circ} \mathrm{C}$ and were sampled after $2,5,10,17,25$, and 48 days of incubation. Sediment slurry samples were taken for analysis of VFAs and sulfate $(1 \mathrm{ml})$, as well as for DNAbased analyses $(0.5 \mathrm{ml})$. Samples were stored on precooled ice packs in the anoxic glovebox and were transferred immediately to the $-80^{\circ} \mathrm{C}$ freezer after sampling. Sampling, processing and molecular biological analyses of sediment samples from Svalbard, Norway, are presented as Supplementary information.

\section{Determination of sulfate and volatile fatty acid concentrations}

Sulfate concentrations in interstitial water samples of microcosms were determined by capillary electrophoresis (P/ACETM MDQ molecular characterization system, Beckman Coulter) with the CEofixTM anions 5 kit (Analis). Standards were produced by dissolving known concentrations of $\mathrm{Na}_{2} \mathrm{SO}_{4}$ in artificial seawater. The concentrations of VFAs were determined as follows: samples were defrosted, vortexed, and centrifuged at 10,000 rpm for $10 \mathrm{~min} .100 \mu \mathrm{l}$ of the supernatant was diluted 1:10 (v/v) in Milli-Q water. Syringe filters (Acrodisc IC grade filter, $d=13 \mathrm{~mm}$, Suprapor membrane with $0.2 \mu \mathrm{m}$ pore size) were first rinsed with $10 \mathrm{ml}$ Milli-Q water followed by $0.5 \mathrm{ml}$ of diluted sample to minimize further dilution with the rinsing water. Another $0.5 \mathrm{ml}$ of sample was then filtered and measured by two-dimensional ion chromatography-mass spectrometry (IC-IC-MS; Dionex ICS-3000 coupled to an MSQ Plus ${ }^{\mathrm{TM}}$, both Thermo Scientific), equipped with an Ion Pack $^{\mathrm{TM}}$ AS 24 as the first column to separate bulk VFAs from chloride, and an Ion Pack ${ }^{\mathrm{TM}} \mathrm{AS} 11 \mathrm{HC}$ as the second column to separate individual VFAs [38].

\section{DNA extraction}

For DNA-SIP gradients and PCR-based amplicon sequencing, DNA was extracted using a combination of bead beating, cetyltrimethylammonium bromide-containing buffer, and phenol-chloroform extractions. Sediment slurry $(0.5 \mathrm{ml})$ was added to Lysing Matrix E tubes (MP Biomedicals) and was suspended in $0.675 \mathrm{ml}$ cetyltrimethylammonium bromide-containing extraction buffer, as described previously [39]. The tubes were placed on a rotary shaker $(200 \mathrm{rpm})$ and incubated at $37^{\circ} \mathrm{C}$ for $30 \mathrm{~min}$. The samples were supplemented with $75 \mu \mathrm{L}$ of sodium dodecyl sulfate $(20 \% \mathrm{w} / \mathrm{v})$ and were then incubated for $1 \mathrm{~h}$ at $65{ }^{\circ} \mathrm{C}$ (tubes were inverted every $20 \mathrm{~min}$ ). Samples were subjected to two rounds of bead beating with a speed setting 6 for $30 \mathrm{~s}$ using a FastPrep -24 bead beater (MP Biomedicals). In between the beat beating steps, samples were cooled on ice. Debris was pelleted by centrifugation at $6000 \times g$ for $10 \mathrm{~min}$ at $25^{\circ} \mathrm{C}$ and supernatant was collected. An equal volume of phenol:chloroform:isoamyl (25:24:1) alcohol (ROTH) was added to the supernatant and tubes were repeatedly inverted, followed by centrifugation at $16,000 \times g$ for $10 \mathrm{~min}$ at $25^{\circ} \mathrm{C}$. The aqueous phase (upper layer) was transferred into a clean $1.5 \mathrm{ml}$ tube, supplemented with 0.6 volume of 2-propanol, and incubated for $1 \mathrm{~h}$ at $4{ }^{\circ} \mathrm{C}$ to precipitate DNA. The precipitate was then pelleted by centrifugation at $16,000 \times g$ for $30 \mathrm{~min}$ at $4{ }^{\circ} \mathrm{C}$. DNA pellets were washed with $250 \mu \mathrm{L}$ of $70 \%(\mathrm{v} / \mathrm{v})$ ethanol, air-dried, and resuspended in $50 \mu \mathrm{L}$ Tris buffer (10 mM Tris- $\mathrm{HCl}(\mathrm{pH} 8.0)$ ). For metagenome sequencing, DNA was extracted from day 0 and from individual sediment microcosm samples at days 5, 17, and 25 (for both protein and lipid-amended treatments) using the PowerSoil DNA Isolation Kit (MoBio) and following manufacturers' protocol.

\section{DNA-SIP gradients}

$\mathrm{CsCl}$ gradients with $5 \mu \mathrm{g}$ DNA were prepared in a temperature controlled room at $23{ }^{\circ} \mathrm{C}$ according to a previously published protocol [40]. The gradient mixtures were added to ultracentrifuge tubes (Beckman Coulter) and were centrifuged in an Optima L-100XP ultracentrifuge (Beckman Coulter) using the VTi 90 rotor for $>48 \mathrm{~h}$ at $146286 \mathrm{rcf}(44,100 \mathrm{rpm})$ at $20^{\circ} \mathrm{C}$. After centrifugation, gradients were fractionated into $250 \mu \mathrm{l}$ fractions by puncturing the bottom of the tube with a sterile needle and adding water to the gradient tube at the top using a sterile needle and a syringe pump (World Precision Instruments). The density of collected fractions was determined by using a digital refractometer (AR 200, Reichert Analytical Instrument) at $23{ }^{\circ} \mathrm{C}$. The DNA-SIP fractions were considered heavy at densities $>1.726 \mathrm{~g} \mathrm{ml}^{-1}$ and light at densities $<1.720 \mathrm{~g} \mathrm{ml}^{-1}$ (Supplementary Fig. S1). Afterwards, DNA was precipitated with $500 \mu \mathrm{L}$ sterile PEG 6000 (30\% polyethylene glycol 6000 and $1.6 \mathrm{M} \mathrm{NaCl})$ and $1 \mu \mathrm{L}$ of glycogen $\left(5 \mu \mathrm{g} \mathrm{ml}^{-1}\right)$ and 
subsequently purified as described previously [40]. Bacterial DNA in SIP fractions was quantified by quantitative PCR (qPCR) using the primers 341F 5'-CCT ACG GGA GGC AGC AG-3' and 534R 5'-ATT ACG GCG GCT GCT GGC A-3 ${ }^{\prime}$. The $20 \mu \mathrm{L}$ qPCR mix contained $1 \times \mathrm{IQ}^{\mathrm{TM}}$ SYBR Green Supermix (BIO-RAD), $0.25 \mu \mathrm{M}$ of each primer, and $1 \mu \mathrm{L}$ of $1: 10$ diluted DNA from individual gradient fractions. The program used for thermal cycling on the iCycler thermal cycler (Bio-Rad) consisted of: $3 \mathrm{~min}$ at $95^{\circ} \mathrm{C}$, followed by 39 cycles of $95^{\circ} \mathrm{C}$ for $15 \mathrm{~s}$, $60{ }^{\circ} \mathrm{C}$ for $30 \mathrm{~s}$, and $72{ }^{\circ} \mathrm{C}$ for $39 \mathrm{~s}$, and was followed by a melting curve from $60{ }^{\circ} \mathrm{C}$ to $95^{\circ} \mathrm{C}$ by increments of $0.5^{\circ} \mathrm{C}$ every $5 \mathrm{~s}$.

\section{Amplicon sequencing and analysis}

Barcoded 16S rRNA gene amplicons for Illumina MiSeq sequencing were produced using a previously established two-step PCR approach [41, 42]. The primers were based on U519F $5^{\prime}$-CAG CMG CCG CGG TAA TWC-3' and 802R 5'-TAC NVG GGT ATC TAA TCC-3'. Primer coverage was checked using TestProbe against SILVA v138 [43]. Raw reads were processed as described previously [41, 42]. The identity threshold used for OTU clustering was $97 \%$ identity. Sub-OTU diversity at singlenucleotide resolution in the amplicon data was investigated using cluster-free filtering [44]. Statistical significance of differences in OTU relative abundances between treatments was determined using DESeq2 (version 1.10.1) [45] in the $\mathrm{R}$ software environment http://www.r-project.org/index.html. Additionally, an OTU was considered to be ${ }^{13} \mathrm{C}$-enriched when it was significantly more abundant in heavy SIP fractions compared to light fractions obtained from the same incubation [46], which was also determined using DESeq2. The sequence abundance of each OTU in the "heavy" part $\left(>1.726 \mathrm{~g} \mathrm{ml}^{-1}\right)$ of the DNA-SIP gradient (numerator) was compared to sequence abundance in the "light" part $\left(<1.720 \mathrm{~g} \mathrm{ml}^{-1}\right)$ of the DNA-SIP gradient (denominator). Specific samples used for comparisons are indicated in Supplementary Fig. S1. Only OTUs that had $\geq 5$ reads and that were present in $\geq 5$ of the 32 gradient fraction sample data sets were considered for comparisons by DESeq2 analyses. Results were extracted with the command:

results (cooksCutoff $=$ FALSE, altHypothesis $=$ "greater")

and were considered statistically significant if: (1) the false-discovery-rate (FDR)-adjusted $p$ value was below 0.1 , and (2) the respective OTU was not significantly enriched in the heavy fractions of the DNA-SIP gradient from the no-substrate incubations. OTU counts were "rlog" transformed with DESeq2 and heatmaps of enriched OTUs were created with $\mathrm{R}$ software package pheatmap (version 1.0.8).
The presence of 16S rRNA gene sequences related ( $>97 \%$ identity) to specific organisms of interest in publicly available amplicon-derived data sets was determined using the IMNGS server [47], with 100 bp overlap as minimum.

\section{Metagenome sequencing and differential coverage binning}

Metagenome libraries were produced with the Nextera XT DNA Library Preparation Kit (Illumina) and sequencing was performed at the Vienna Biocenter Core Facilities Next Generation Sequencing facility (Vienna, Austria) on an Illumina Hiseq2500 using HiSeq V4 chemistry with the $125 \mathrm{bp}$ paired-end mode. Reads were end trimmed at the first base with a $q$ score below 10 and reads with $<50 \mathrm{bp}$ were removed. For assembly, sequence coverage was normalized across samples using bbnorm with an average read depth of 100 and a minimum read depth of 3 (BBmap version $33.57 \mathrm{http} / / /$ sourceforge.net/projects/bbmap/). Normalized read files were assembled with IDBA-UD [48] and SPAdes [49] using default parameters. Reads of each sample (non-normalized) were mapped to each assembly using BWA [50], and coverage information was obtained using SAMtools [51]. Differential coverage binning was performed with MetaBAT [52], MaxBin [53], and CONCOCT [54]. Following the binning programs default parameters, only contigs with a minimum length of 2500 and $1000 \mathrm{bp}$ were used for binning with MetaBAT and MaxBin/ CONCOCT, respectively. The resulting metagenomeassembled genomes (MAGs) generated from different assemblies and binning programs were aggregated with DASTool [55], and de-replicated with dRep using default parameters [56]. MAGs that could be linked to ${ }^{13} \mathrm{C}$ incorporating OTUs during protein and lipid hydrolysis by 16S rRNA gene sequence identity were further analyzed. Selected MAGs were evaluated for completion and contamination using CheckM [57], and classified using the Genome Taxonomy Database (GTDB) release 86 [58] and GTDB-Tk version 0.1.3 [59]. For a genome-based phylogenetic analysis of MAGs, the genome of the type strain Psychrilyobacter atlanticus HAW-EB21 and closely related reference genomes, was constructed from the concatenated marker protein alignment produced by CheckM [57]. The phylogenetic tree was built from this concatenated marker alignment with IQ-TREE using automatic substitution model selection (LG + F+ I+ G4) [60] and ultrafast bootstrap approximation with 1000 replicates [61]. The tree was visualized with iTOL [62]. Average nucleotide identities (ANI) and average amino acid identities (AAI) of selected MAGs and closely related reference genomes were determined using allvs-all FastANI 1.1 with default parameters [63] and CompareM 0.0.23 (aai_wf) with default parameters (https://github. com/dparks1134/CompareM), respectively. 
Fig. 1 Concentration profiles of sulfate and fermentation products in subarctic marine sediment microcosms.

Concentrations of sulfate (A) and volatile fatty acids (B) were determined in anoxic

incubations with ${ }^{13} \mathrm{C}$-protein or

${ }^{13} \mathrm{C}$-lipids, and with or without the sulfate reduction inhibitor molybdate. Control microcosms were incubated without organic substrates and without molybdate.

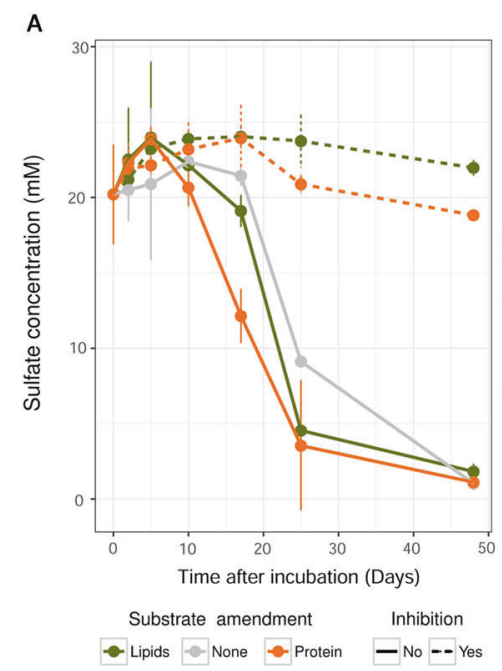

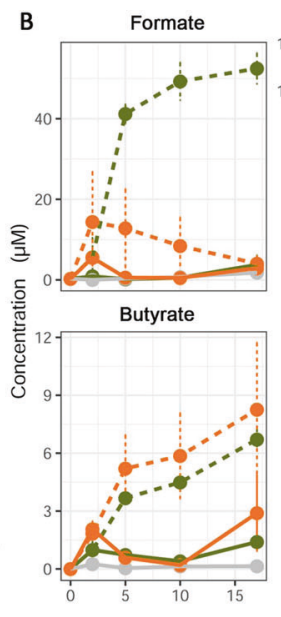
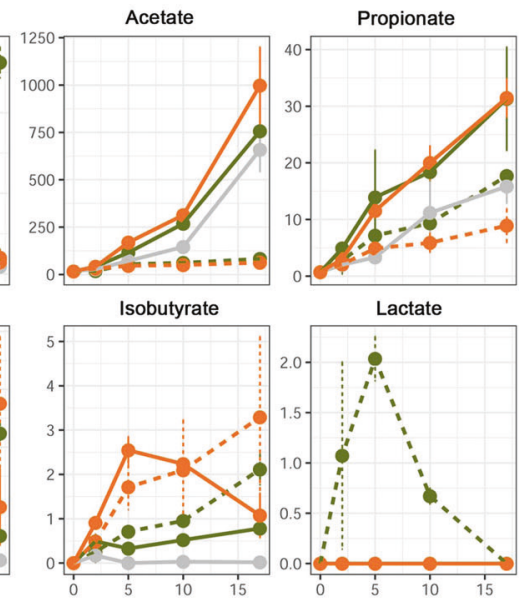

Time after incubation (Days)

\section{Genome annotation}

MAGs were annotated with the MicroScope annotation platform [64] and using the RAST server [65]. The annotations of proteins were confirmed by DIAMOND searches [66] against the NCBI-nr database ( $e$ value $10^{-5}$ ), hidden Markov model-based searches using InterProScan [67] with the databases Pfam-A [68] and TIGRFAM [69], and online BLASTP searches against the UniProt database [70]. Possible hydrolytic enzymes were examined for signal peptide sequences that facilitate secretion from the cytoplasm and transmembrane helices using the Phobius online server [71] and using PSORTb version 3.0 [72]. Furthermore, peptidases, lipases/esterases, and glycoside hydrolases were additionally compared to the databases MEROPS [73], ESTHER [74], and CAZY [75], respectively, using DIAMOND searches ( $e$ value $>10^{-5}$, identity $\geq 30 \%$ ). Furthermore, searches were made against the NCBI-nr database using BLASTP [76] for certain proteins of interest. The selection of potentially catabolic peptidases encoded by genomes and MAGs was based on two recent studies about extracellular peptidases in marine sediments [29, 77]. In addition, non-peptidase homologs and peptidases with regulatory functions, e.g., peptidases involved in membrane protein remodeling, as indicated by MEROPS database descriptions, were not considered (Supplementary Table S1). Potentially catabolic lipases/esterases were selected based on the ESTHER database descriptions (Supplementary Table S1).

\section{Phylogenetic analyses of 16S rRNA gene sequences}

16S rRNA gene sequences were aligned and classified with the SINA aligner [78], using the SILVA database release 128 [43]. Full-length sequences of close relatives of $16 \mathrm{~S}$ rRNA OTUs were extracted from the SILVA database and combined with the aligned 16S rRNA genes sequences that were obtained from MAGs. A reference tree was then constructed using FastTree [79]. Subsequently, 16S rRNA OTUS and partial 16S rRNA genes from MAGs were added to the reference tree using the EPA algorithm [80] in RAxML [81]. Trees were visualized in iTOL [62].

\section{Statistical analyses}

Statistics for comparisons of VFAs and sulfate in treatment series versus controls were determined with Student's $t$ tests using the function t.test() in the R software environment.

\section{Results}

\section{Sulfate removal and volatile fatty acid turnover during protein and lipid degradation}

Sulfate was largely turned over after 48 days in all incubation treatments (down to $0.6-2.4 \mathrm{mM}$ ), except in incubations where sulfate reduction was inhibited by molybdate, where it remained between 18.1 and $24.2 \mathrm{mM}$ (Fig. 1A). Sulfate turnover was fastest between days 5 and 25, and was stimulated by the additions of proteins or lipids. Of all measured VFAs, acetate was the most prominent, reaching concentrations of over $900 \mu \mathrm{M}$ in protein-amended microcosms on day 17. Formation of the next most abundant VFA, formate, peaked at around $50 \mu \mathrm{M}$ in lipid/molybdateamended microcosms. Supplementation of proteins to the incubations resulted in significantly higher concentrations of acetate from days 2 to 5 compared to no-substrate controls (Supplementary Table S2). While the stimulation of acetate production from lipid additions was noticeably higher than in no-substrate controls, the differences were not statistically significant (Supplementary Table S2). 


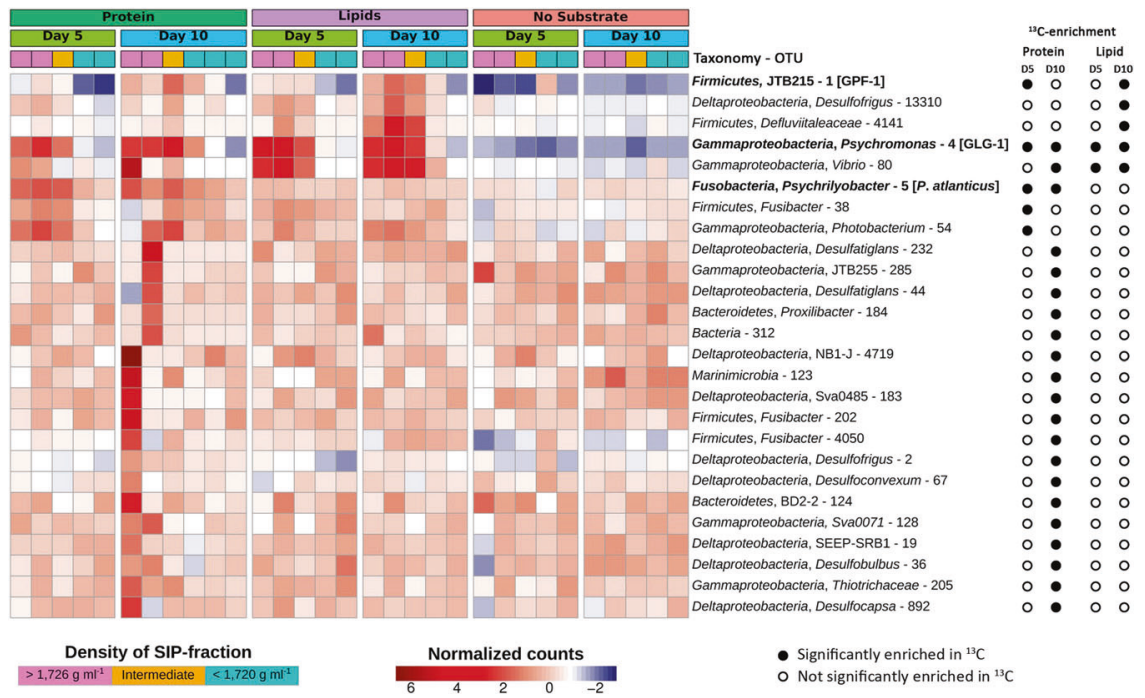

Fig. 2 16S rRNA gene OTUs enriched in heavy ${ }^{13} \mathrm{C}$-DNA-SIP gradient fractions. Heatmaps showing the relative abundance of $16 \mathrm{~S}$ rRNA gene OTUs in DNA-SIP gradient fractions from anoxic sediment incubations amended with ${ }^{13} \mathrm{C}$-proteins or ${ }^{13} \mathrm{C}$-lipids and from unamended control incubations. Significant (FDR-adjusted $p$ value was $<0.1){ }^{13} \mathrm{C}$-enrichment was determined by differential abundance

Significantly more propionate, butyrate and isobutyrate were produced in protein- and lipid-amended microcosms, as compared to the no-substrate controls (mainly between 2 and 5 days) (Fig. 1B and Supplementary Table S2). Molybdate-inhibited incubations supplemented with proteins or lipids showed increased accumulation of formate, butyrate, and isobutyrate, but decreased production of acetate and propionate.

\section{${ }^{13} \mathrm{C}$-labeling of OTUs and sub-OTUs during protein and lipid degradation}

To evaluate incorporation of ${ }^{13} \mathrm{C}$ from the added ${ }^{13} \mathrm{C}$ labeled proteins or lipids into the DNA of microorganisms, bacterial 16S rRNA genes were quantified by qPCR across individual SIP fractions (Supplementary Fig. S1). Higher relative copy numbers were detected in the "heavy" fractions of the gradients (i.e., densities $>1.726 \mathrm{~g} \mathrm{ml}^{-1}$ ) from both ${ }^{13} \mathrm{C}$-protein and ${ }^{13} \mathrm{C}$-lipid incubations relative to corresponding no-substrate controls at days 5 and 10. This indicated ${ }^{13} \mathrm{C}$-uptake and incorporation into DNA at these early time points. At days 17 and 25, only very small or no differences in relative 16S rRNA gene copy numbers between gradients from the ${ }^{13} \mathrm{C}$-substrate incubations and the no-substrate control incubations were observed.

Bacterial community analysis of SIP fractions by $16 \mathrm{~S}$ rRNA gene amplicon sequencing identified five OTUs that affiliated with various taxa, i.e., Clostridia-JTB215 OTU 1, Psychromonas OTU 4, Psychrilyobacter OTU 5, Fusibacter-related OTU 38, and Photobacterium OTU 54, were analysis between high density $\left({ }^{13} \mathrm{C}\right.$-enriched, $>1.726 \mathrm{~g} \mathrm{ml}^{-1}$, pink blocks) and low density $\left({ }^{13} \mathrm{C}\right.$-free, $<1.720 \mathrm{~g} \mathrm{ml}^{-1}$, turquoise blocks) DNA, and is indicated by filled circles. 16S rRNA genes that were matched to $16 \mathrm{~S}$ rRNA gene sequences of genomes/MAGs are indicated in bold.

significantly enriched in heavy SIP fractions from the ${ }^{13} \mathrm{C}$ protein incubations at day 5 (Fig. 2A and Supplementary Table S3). At day 10, another 19 OTUs were significantly enriched in heavy SIP fractions from incubations with ${ }^{13} \mathrm{C}$ protein amendments (Fig. 2A). These were affiliated with the classes Deltaproteobacteria (OTUs 2, 19, 36, 44, 67, 183, 232, 892, 4719), Gammaproteobacteria (OTUs 80, $128,205,285$ ) and the phyla Bacteroidetes (OTUs 124 and 184), Firmicutes (OTUs 202 and 4050), and Marinimicrobia (OTU 123), or were unclassified (OTU 312) (Supplementary Fig. S2).

In SIP gradients from ${ }^{13} \mathrm{C}$-lipid-amended incubations at day 5 , significant ${ }^{13} \mathrm{C}$-enrichment was revealed for only two gammaproteobacterial OTUs, i.e., Psychromonas OTU 4 and Vibrio OTU 80 (Fig. 2). An analysis of the microdiversity within Psychromonas OTU 4 identified four Psychromonas sub-OTUs (sub-OTUs 4, 192, 9, and 43) that responded differently in incubations with protein or lipid amendments. The sub-OTUs 4 and 192 were significantly enriched in heavy fractions of ${ }^{13} \mathrm{C}$-lipid incubations (Fig. 3A) and were more closely related to each other than to sub-OTUs 9 and 43 (Fig. 3B). Furthermore, the relative abundance of sub-OTUs 4 and 192 increased in the microcosms from ${ }^{13} \mathrm{C}$-lipid incubations compared to nosubstrate control microcosms (Fig. 3C). In contrast, the subOTUs 9 and 43 were significantly enriched in heavy SIP fractions from ${ }^{13} \mathrm{C}$-protein incubations, and sub-OTU 9 increased in relative abundance in the microcosms from ${ }^{13} \mathrm{C}$-protein incubations compared to no-substrate control microcosms (Fig. 3C). No sub-OTU microdiversity was 


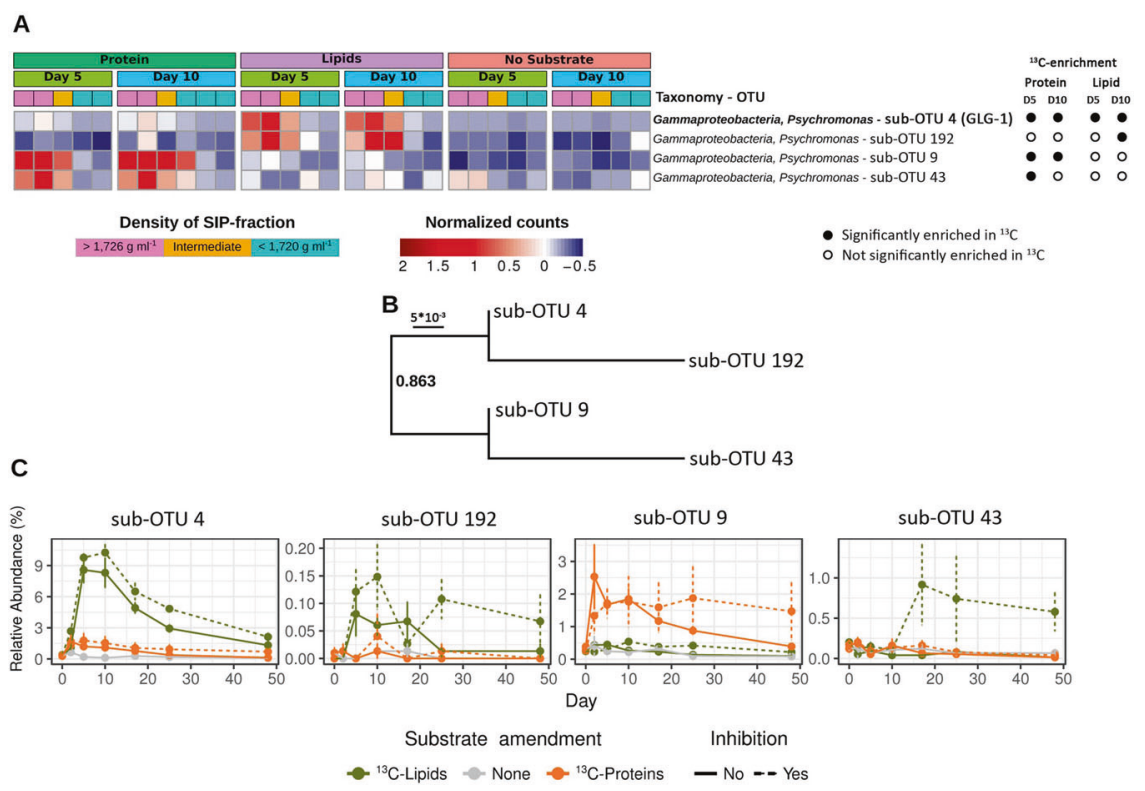

Fig. 3 Differential ${ }^{13} \mathrm{C}$-labeling and response of Psychromonas subOTUs in protein- and lipid-amended sediment microcosms. A Heatmap showing the relative abundance of four sub-OTUs of Psychromonas 16S rRNA OTU 4 in DNA-SIP gradients. Significant ${ }^{13} \mathrm{C}$-enrichment was determined by differential abundance analysis between high density $\left({ }^{13} \mathrm{C}\right.$-enriched) and low density $\left({ }^{12} \mathrm{C}\right.$-enriched) DNA-SIP fractions. Sub-OTU 4, which was identical to the $16 \mathrm{~S}$ rRNA

detected in any other OTU that was significantly enriched in ${ }^{13} \mathrm{C}$. At day 10, we identified three additional OTUs enriched in the heavy SIP fractions from ${ }^{13} \mathrm{C}$-lipid incubations that were affiliated with the phylum Firmicutes (OTUs 1 and 4141) and the class Deltaproteobacteria (OTU 13310) (Fig. 2A).

We also compared the relative abundances of $16 \mathrm{~S}$ rRNA OTUs among the protein- or lipid-amended microcosms versus no-substrate control microcosms over time. Here, we restricted the analysis to OTUs $(n=26)$ that were enriched in ${ }^{13} \mathrm{C}$ from the protein- and lipid-amended treatments (described above). Between days 5 and 10, ten OTUs (1, 2, $4,5,19,54,80,285,4141$, and 13310) significantly increased in relative abundances in substrate-amended incubations as compared to the no-substrate controls (Supplementary Fig. S3A and Supplementary Table S2). Most notably, several OTUs showed comparably large differences in relative abundances between amended and nosubstrate controls, and consequently had high relative abundances among the overall communities. For instance, Psychrilyobacter OTU 5 reached relative abundances of around $9-10 \%$ after $2-5$ days in protein-amended microcosms, while staying around 3-4\% in no-substrate controls. Psychromonas OTU 4 reached relative abundances of around $15-16 \%$ between 5 and 10 days after lipid amendments, while also reaching around $5-7 \%$ in the proteinamended microcosms from days 2 to 10 . In contrast, gene sequence of Psychromonas MAG GLG-1, is indicated in bold. B Phylogeny of Psychromonas sub-OTUs. The sequences were aligned with MAFFT [89] and the tree was calculated with FastTree [79]. C Changes in relative abundance of Psychromonas sub-OTUs in protein-amended, lipid-amended, and unamended sediment microcosms with or without the sulfate reduction inhibitor molybdate.

Psychromonas OTU 4 stayed below $2.5 \%$ in the nosubstrate controls over time. The relatively fast $(<10$ days $)$ and clear increases in relative abundances of these OTUs due to substrate additions therefore provided evidence for their direct involvement in substrate utilization for growth. On the contrary, the Clostridia-JTB215 OTU 1 also showed large increases in relative abundances from both protein and lipid amendments versus no-substrate controls, however, the response was relatively delayed, i.e., such increases developed mainly after 10 days.

Relative abundances of OTUs 1, 2, 67, 4050, and 4141 were significantly lower in microcosms with the sulfatereduction-inhibitor molybdate than in microcosms without molybdate. This suggests that these OTUs are SRM or dependent on SRM activity.

\section{Genomic evidence for extracellular hydrolysis of proteins and lipids}

Samples from day 0 , and from days 5, 17, and 25 from the lipid- and protein-amended microcosms were selected for metagenome sequencing. The aim was to recover genomes of organisms that were ${ }^{13} \mathrm{C}$-labeled from protein or lipid treatments, and to specifically analyze their catabolic potentials for these macromolecules. Overall, nine MAGs were recovered with $>80 \%$ completeness and $<5 \%$ contamination. Two had 16S rRNA sequences identical to 
bacterial OTUs that incorporated ${ }^{13} \mathrm{C}$ from protein or lipid hydrolysis, i.e., Psychromonas MAG GLG-1 and Clostridia MAG GPF-1 (Supplementary Fig. S2). All MAGs that were affiliated with the genus Psychrilyobacter were very incomplete $(<20 \%)$ (data not shown). Therefore, we analyzed the publicly available genome of the type strain $P$. atlanticus HAW-EB21. This strain was isolated from marine sediments [82], and had a 16S rRNA sequence that was identical to Psychrilyobacter OTU 5 that was labeled from protein amendments (Supplementary Fig. S2). A Desulfoluna MAG GLD-1 was also analyzed in detail because it encoded potential to degrade VFAs and/or lipids, although it could not be confidently linked to any $16 \mathrm{~S}$ rRNA OTU sequence.

Psychromonas MAG GLG-1 was most closely related to Psychromonas aquimarina ATCC BAA-1526 (ANI 80.7\% of $41.8 \%$ aligned) (Supplementary Table S4) and encoded a 16S rRNA sequence that was identical to Psychromonas sub-OTU 4 (Supplementary Fig. S2). Clostridia MAG GPF-1 was only distantly related to any publicly available genome (Supplementary Fig. S4), with an AAI of only $53.4 \%$ (of 37\% aligned) (ANI was too low to calculate) to the most-related genome of Caloranaerobacter azorensis DSM 13643 (Supplementary Table S4). A short 16S rRNA fragment (92 bp) was retrieved from Clostridia MAG GPF1 and was linked to the $16 \mathrm{~S}$ rRNA OTU 1 by phylogenetic placement into a reference tree (Supplementary Fig. S2). The genomes/MAGs of putative protein and/or lipid degraders were subsequently analyzed for encoded capabilities to degrade proteins ( $P$. atlanticus corresponding to 16S rRNA OTU 5), lipids (Psychromonas MAG GLG-1 corresponding to sub-OTU 4) or both macromolecules (Clostridia MAG GPF-1 corresponding to 16S rRNA OTU 1).

The genome of $P$. atlanticus HAW-EB21 encodes a variety of peptidases $(n=24)$, which were likely involved in the breakdown of peptides for further catabolism of amino acids (Supplementary Table S5). Two of these peptidases (i.e., M3 and M24) encoded signal peptides for translocation across the cytoplasmic membrane (Fig. 4). Overall, the genome of $P$. atlanticus encodes an array of predicted peptide $(n=19)$ and amino acid transporters $(n=38)$, especially when compared to the MAGs of the putative lipid degraders Psychromonas MAG GLG-1 (peptide transporter, $n=6$; amino acid transporter, $n=14$ ) (Supplementary Table S5). Furthermore, the genome of $P$. atlanticus was encoded for proton-dependent peptide transportation (Supplementary Table S5).

The lipid-metabolizing capability of Psychromonas MAG GLG-1 was supported by the presence of genes for an extracellular phospholipase D/alkaline phosphatase and a carboxylesterase with a signal peptide sequence, which corresponded to the ESTHER family carboxylesterase type
B (Supplementary Table S5). The long-chain fatty acids that resulted from extracellular degradation of acyl chain esters were likely taken-up by cells via two predicted long-chain fatty acid transporters (Supplementary Table S5). Predicted glycerol transporters were not encoded in the genome of Psychromonas MAG GLG-1. Because our study revealed Psychromonas spp. to be potentially important lipid and protein degraders, we also investigated available genomes and/or MAGs $(n=16)$ from publicly available databases in order to examine the prevalence of the encoded capacity to utilize extracellular proteins or lipids via extracellular hydrolases (Supplementary Fig. S5 and Supplementary Table S6). This identified predicted secreted phospholipases in most genomes $(n=10)$, while predicted secreted proteases/peptidases were restricted to four genomes (Supplementary Fig. S5 and Supplementary Table S6).

Clostridia MAG GPF-1 encoded the largest number of peptidases $(n=29)$ of all analyzed MAGs/genomes (Supplementary Table S5). Three of these peptidases (M20, M24, and S8 peptidase families) have predicted secretion signal peptides and might be excreted from the cytoplasm via the SEC pathway (Fig. 4). Similar to P. atlanticus, Clostridia MAG GPF-1 encoded a broad array of predicted peptide $(n=14)$ and amino acid $(n=24)$ transporters. In accordance with the DNA-SIP results, Clostridia MAG GPF-1 also has the potential for catabolic breakdown of lipids. The MAG encoded one potentially secreted catabolic esterase/lipase that correspond to the ESTHER family Bacterial_EstLip_FamX, and two predicted membranebound esterases/lipases that correspond to the ESTHER families Bacterial_EstLip_Fam and carboxylesterase, type B (Supplementary Table S5). The presence of genes for esterases/lipases in the genome of Clostridia MAG GPF-1 indicated the potential of this MAG to hydrolyze ester bonds between glycerol and fatty acids. Because genes encoding for known fatty acid transport and catabolism were absent from the genome of Clostridia MAG GPF-1, this bacterium might instead utilize glycerol. This was supported by an encoded glycerol-3-phosphate transporter and a putative glycerol facilitator protein, which were also encoded directly adjacent to a glycerol kinase, which catalyses the first step of the cytoplasmic catabolism of this substrate (Supplementary Table S5).

\section{Intracellular catabolism of protein and lipid degradation intermediates}

The genome of $P$. atlanticus encoded 22 cytoplasmic peptidases with possible catabolic roles (Supplementary Table S5). In comparison, the genomes of the putative lipid degrader, i.e., Psychromonas MAG GLG-1 encoded only seven intracellular peptidases. In this study, we focused on amino acid degradation processes that form glutamate and/ 


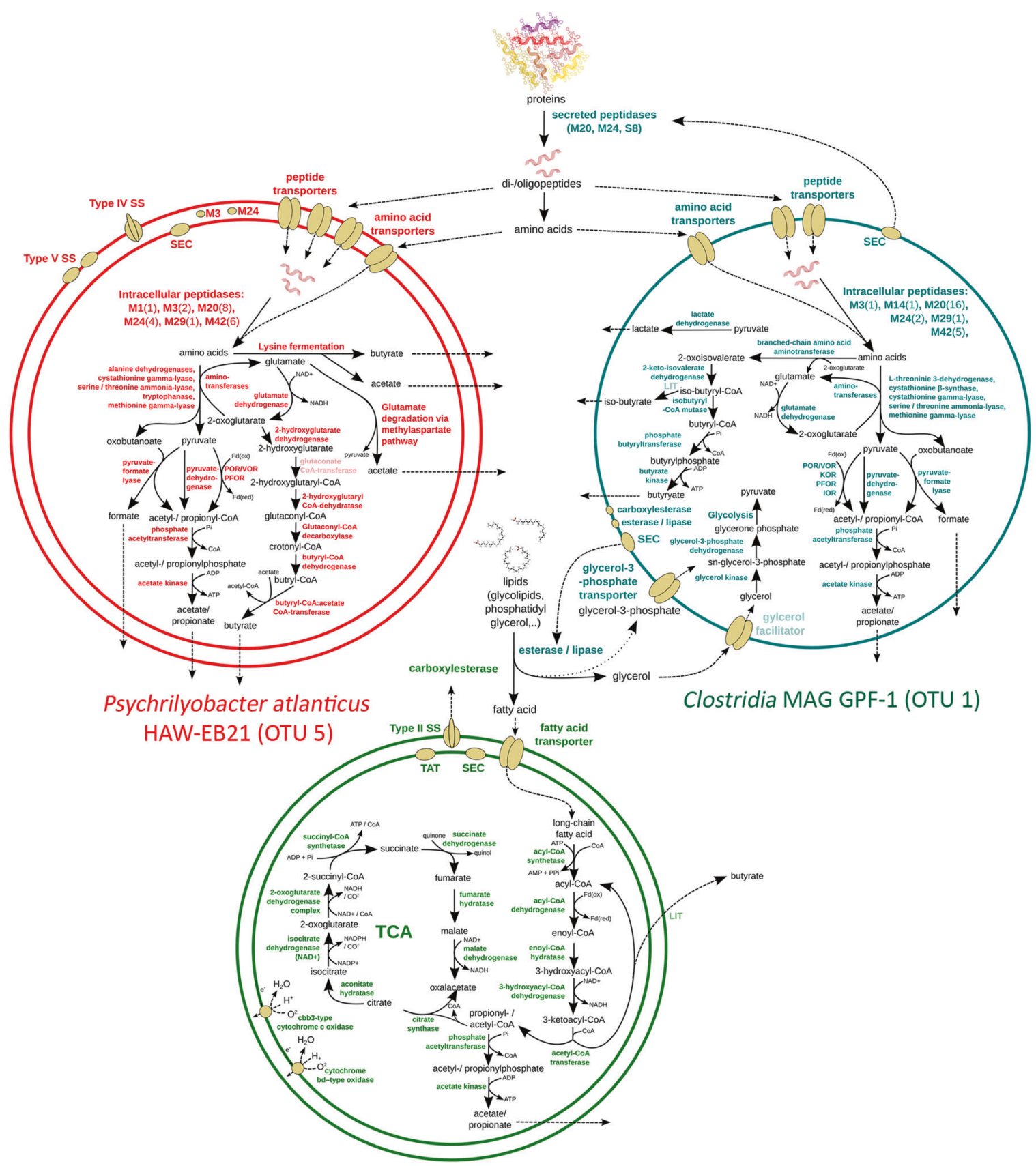

Psychromonas MAG GLG-1 (sub-OTU 4)

Fig. 4 Genome-inferred metabolic models of protein- and lipiddegrading bacteria in arctic marine sediment. Schematic depiction of predicted metabolic properties of Psychrilyobacter atlanticus, Clostridia MAG GPF-1, and Psychromonas MAG GLG-1, which correspond to the $16 \mathrm{~S}$ rRNA OTUs 5,1 , and sub-OTU 4 , respectively (indicated in parenthesis). The models indicate macromolecule degradation processes and enzymes that may explain the observed

or keto-acids for central carbon metabolism and that could therefore explain incorporation of ${ }^{13} \mathrm{C}$-carbon from the ${ }^{13} \mathrm{C}$ labeled proteins into DNA, as well as the development of VFAs in our incubations (Fig. 4). The genome of $P$. atlanticus encoded several aminotransferases and other biogeochemical patterns and the ${ }^{13} \mathrm{C}$-enrichment of corresponding $16 \mathrm{~S}$ rRNA OTUs in the DNA-SIP incubations. Enzymes that are indicated in pale color were not found in the respective genome/MAG. SS secretion system, TCA tricarboxylic acid cycle, TAT twin-arginine translocation pathway, SEC Sec secretion system; LIT process has physiological evidence but the involved enzymes are not identified yet.

amino acid degrading enzymes (i.e., alanine dehydrogenases, cystathionine gamma-lyase, serine/threonine ammonia-lyase, tryptophanase, and methionine gammalyase) (Supplementary Table S5). These can convert amino acids to the keto-acids pyruvate and oxobutanoate, which 
could then be fermented to formate, and either acetate or propionate, respectively (Fig. 4).

Psychromonas MAG GLG-1 encoded all enzymes required for beta-oxidation of fatty acids, including a putative multienzyme complex that contains the two enzymes enoyl-CoA hydratase/isomerase and 3hydroxyacyl-CoA dehydrogenase (Supplementary Table S5). Through beta-oxidation, even- and odd-chain fatty acids can be converted to propionyl- and acetylCoA, which can be further fermented to acetate and propionate, respectively (Fig. 4). In comparison to P. atlanticus and Clostridia MAG GPF-1, which encoded strict fermentative metabolisms, Psychromonas MAG GLG-1 also encoded a complete oxidative TCA cycle, which enables a respiratory conversion of acetyl-CoA to $\mathrm{CO}_{2}$ (Fig. 4). When oxygen is available, Psychromonas MAG GLG-1 might use one of the two encoded high affinity oxidases for respiration, i.e., cbb3-type cytochrome $c$ oxidase and cytochrome $b d$-type oxidase (Supplementary Table S5). In oxygen-depleted sediments like in our microcosm incubations, Psychromonas GLG-1 might ferment, or may respire using nitrate (dissimilatory nitrate reduction to ammonium) or fumarate as terminal electron acceptors (Supplementary Table S5). Genes necessary for the intracellular degradation of glycerol were absent from Psychromonas MAG GLG-1 (Supplementary Table S5). Furthermore, despite the presence of genes for several extracellular glycosyl hydrolases in the genome of Psychromonas MAG GLG-1 and a complete glycolysis pathway (Supplementary Table S5), enzymes for feeding galactose or glycerol (subcomponents of Spirulinaderived galactosyl diglycerides), into glycolysis, were not identified.

The Clostridia MAG GPF-1 encoded the largest set of intracellular peptidases $(n=26)$ of all investigated genomes (Supplementary Table S5). The fermentation of amino acids by Clostridia GPF-1 to propionate, acetate, or formate, i.e., via aminotransferases and other amino acid degrading enzymes (i.e., L-threonine 3-dehydrogenase, cystathionine $\beta$-synthase, cystathionine gamma-lyase, serine/threonine ammonia-lyase, and methionine gamma-lyase), was mostly similar to the predicted routes used by $P$. atlanticus, although genes for lysine fermentation were not present and the glutamate degradation pathways were incomplete (Supplementary Table S5). In addition, the Clostridia MAG GPF-1 was the only MAG that encoded enzymes that initiate valine degradation, i.e., two branched-chain amino acid transferases and the gene 2-keto-isovalerate dehydrogenase that is part of the branched-chain $\alpha$-keto acid dehydrogenase complex (Supplementary Table S5). Besides the potential for amino acid degradation, Clostridia MAG GPF-1 also encoded all genes necessary for the conversion of glycerol and glycerol-3-phosphate to pyruvate
(Supplementary Table S5), which may help explain with the ${ }^{13} \mathrm{C}$-enrichment of $16 \mathrm{~S}$ rRNA OTU 1 in ${ }^{13} \mathrm{C}$-lipid-amended incubations (Fig. 2).

\section{A putative sulfate-reducing Desulfoluna MAG GLD-1 with potential to use VFAs and long-chain fatty acids}

The deltaproteobacterial Desulfoluna MAG GLD-1 encoded the capacity to utilize various VFAs and potentially lipids/long-chain fatty acids. In addition to several acylCoA synthetases, it encoded a butanoate CoA-transferase that enables conversion of butyrate to butyryl-CoA, which can then be funneled into beta-oxidation (Fig. 5). For lactate degradation, GLD-1 encoded several lactate dehydrogenases and a lactate utilization operon (Supplementary Table 5). Desulfoluna MAG GLD-1 also encoded a formate dehydrogenase enzyme complex (Supplementary Table 5) to oxidize formate to $\mathrm{CO}_{2}$ and $\mathrm{H}_{2}$ (Fig. 5). Furthermore, the potential to utilize lipids and long-chain fatty acids was indicated by genes for an outer membrane phospholipase A, a long-chain fatty acid transporter, and multiple long-chain fatty acid CoA ligases (Supplementary Table 5), all with high similarity to homologs from other known long-chain fatty acid- and lipid-degrading SRM. The Desulfoluna MAG GLD-1 encoded the complete pathway for dissimilatory sulfate reduction (Fig. 5).

\section{Environmental distributions of key taxa}

To explore fine-scale depth distributions of the main primary-hydrolyzing Psychromonas and Psychrilyobacter species in sulfidic arctic marine sediments, we examined 16S rRNA-gene and -cDNA derived sequence data sets from sediments of Smeerenburgfjorden, Svalbard (Supplementary Fig. S6). This showed that Psychromonas sequences reached $1.7 \%$ and $1.9 \%$ relative abundances in 16S rRNA-gene and -cDNA libraries in $0-1$ centimetres below seafloor (cmbsf) samples from Station GK, respectively. In a nearby core from Station J, they also reached $1.2 \%$ relative abundances in both $16 \mathrm{~S}$ rRNA-gene and -cDNA libraries in 0-1 cmbsf samples. At both sites, relative abundances of Psychromonas 16S rRNA-genes and -transcripts were very low under $3 \mathrm{cmbsf}$ (Supplementary Fig. S6). Sequences from the Psychrilyobacter reached only $0.3 \%$ in $0-1$ cmbsf from Station $\mathbf{J}$ samples and comprised maximally only $0.05 \%$ of the $16 \mathrm{~S}$ rRNA transcripts in the same sample (results not shown). Psychrilyobacter sequences were under $0.03 \%$ in all other samples deeper than $1 \mathrm{cmbsf}$. Furthermore, to gauge their prevalence in other marine sediments, we examined sequences that were similar ( $>97 \%$ identity) to the Psychromonas and Psychrilyobacter OTUs recovered in this study to sequences in 
Fig. 5 Genome-inferred metabolic model of Desulfoluna MAG GLD-1. SS secretion system, TCA tricarboxylic acid cycle, TAT twin-arginine translocation system.

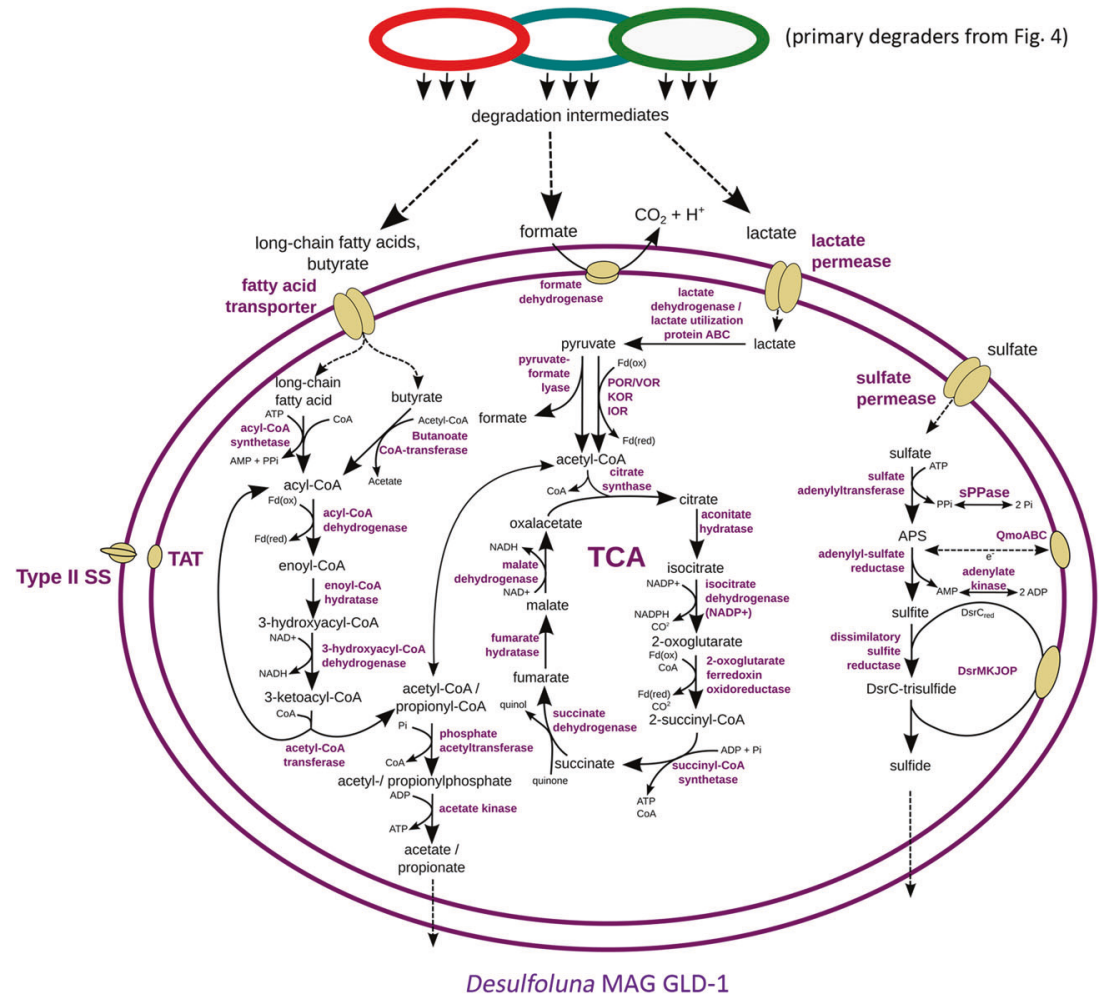

5 days. This was also paralleled by sharp increases in the relative abundances by many of the same taxa in the corresponding microcosms. We therefore reasoned that taxa that were ${ }^{13} \mathrm{C}$-labeled and stimulated to higher relative abundances $(>1 \%)$ within the first 5 days represented the main primary hydrolysers and fermenters of proteins or lipids. Thus, the following discussion especially focuses on these primary-hydrolyzing taxa.

Overall, more diverse OTUs incorporated ${ }^{13} \mathrm{C}$-carbon from proteins compared to lipids, especially after 10 days of incubation, possibly due to a combination of: (1) higher proportions and bioavailability of proteins in sediments $[8,9],(2)$ greater nutritional value of proteins (e.g., nitrogen), and/or (3) a greater biodegradability of proteins as compared to lipids [84]. Sediment microorganisms are also known to efficiently salvage organic nitrogen sources such as amino acids in times of low nutrient supply [11]. Therefore, some microorganisms may have salvaged free peptides or amino acids released from the primary hydrolysers and became ${ }^{13} \mathrm{C}$-labeled.

The Psychromonas 16S rRNA gene OTU 4 was notable in this study because our DNA-SIP results showed that it was a prominent degrader of both lipids and proteins. Interestingly, we could distinguish four sub-OTUs that each had distinct preferences for either lipids or proteins. Thus, this demonstrated that closely related populations of Psychromonas in marine sediments can have very different preferences for macromolecules that require completely different catabolic machinery. From the metagenomic 
analyses, the Psychromonas MAG GLG-1, which represented the lipid-degrading sub-OTU 4 population, indeed had gene content that supported its capacity to digest lipids and catabolize fatty acids. For instance, it encoded a secreted esterase/lipase to digest lipids from the extracellular environment, as well as long-chain fatty acid transporters and a beta-oxidation pathway to import and catabolize the fatty acids (Fig. 4). Although we did not recover any Psychromonas MAGs representative of the protein-degrading populations, comparative genomic analyses of publicly available Psychromonas genomes and MAGs showed that predicted secreted lipases and/or peptidases are common among this genus (Supplementary Fig. S5). Diverse members of this genus therefore have unique potentials to utilize lipids or proteins. An alternative possibility is that the Psychromonas sub-OTU 9 population may have become ${ }^{13} \mathrm{C}$-labeled after taking-up free amino acids released by other primary degraders. Yet if this was the case, one could expect that many other taxa would have been ${ }^{13} \mathrm{C}$-labeled at day 5 , however, this was not apparent. It therefore points to the direct involvement of the Psychromonas sub-OTU 9 in the primary degradation of proteins.

Our bacterial community profiling showed that Psychromonas were relatively abundant and active (based on 16S rRNA expression) in shallow sediments $(<3 \mathrm{cmbsf})$ from arctic Svalbard. Psychromonas were previously shown to be highly correlated with fluxes of fresh phytodetritus to surface sediments of the arctic Laptev Sea [85]. Together with our experimental and genomic analyses, this suggests that Psychromonas play an active role in the turnover of "fresh" and labile organic matter delivered to surface marine sediments from the water column. This is in line with previous experiments that showed Psychromonas were important players in the initial degradation of whole Spirulina (cyanobacterial) necromass in arctic marine sediment [23]. This may be explained by the high amounts of protein in such necromass. Our study therefore suggests that Psychromonas populations thrive in surface sediments by utilizing abundant macromolecules that represent fresh and labile organic matter, e.g., lipids and/or proteins.

We further showed that Psychrilyobacter OTU 5 was one of the most prominent protein and/or amino acid degraders in our experiment. Members of this genus were also shown to be important degraders of whole Spirulina necromass in marine sediment experiments [23, 34]. Here, we therefore deciphered their role in bulk organic matter degradation by showing that they are efficient degraders of detrital protein/ peptides. Correspondingly, genomic analyses showed that the $P$. atlanticus type strain HAW-EB21 [82], which had $100 \% 16 \mathrm{~S}$ rRNA sequence identity to OTU 5 , encoded various routes for the degradation of peptides and for the subsequent fermentation of amino acids (Fig. 4) [82]. Their overall contributions to protein degradation in marine sediments may, however, be less than the Psychromonas because they were not abundant members of most sedimentary microbiomes analyzed.

The Clostridia MAG GPF-1 (16S rRNA OTU 1) had $<54 \%$ AAI to any available genome, and therefore our data represent the first insights into the potential metabolism of this uncultured group. Overall, our analyses suggested that these organisms are versatile organic molecule utilizers. The Clostridia OTU 1 population was ${ }^{13} \mathrm{C}$-labeled in SIP analyses from both ${ }^{13} \mathrm{C}$-protein and -lipid incubations, and its relative abundances were also increased by the additions of both substrates, although to a much lower extent than for Psychromonas or Psychrilyobacter. Our genomic analyses indicated the potential to utilize peptides, amino acids, and glycerol (Fig. 4), thereby highlighting its versatility. Furthermore, OTU 1 also increased in no-substrate controls over time, suggesting it either utilized natural organic matter in the microcosms, or fermentation products produced from the degradation of the natural organic matter by other members of the community.

In addition to the relatively abundant taxa described above that were ${ }^{13} \mathrm{C}$-enriched and that could be linked to genomes or MAGs, we also identified ${ }^{13} \mathrm{C}$-enrichment in several low abundance taxa $(<1 \%$ relative abundances), i.e., members of the genera Photobacterium (OTU 54), Vibrio (OTU 80), and Fusibacter-related OTU 38. These taxa may have therefore played a less prominent role in the primary hydrolysis of the macromolecules and are therefore discussed briefly in the Supplementary Discussion.

After the main primary degradation processes and increased formation of fermentation products (i.e., VFAs) in the first 5 days, ongoing depletion of sulfate and inhibition of sulfate depletion by molybdate indicated SRM were active. Various taxa including Deltaproteobacteria related to known SRM became ${ }^{13} \mathrm{C}$-labeled at day 10 , which suggested transfer of carbon from the added macromolecules to SRM. This was likely via oxidation of the VFAs by the SRM, because deltaproteobacterial SRM are known to be important oxidizers of fermentation products in marine sediments [33, 86, 87]. A deltaproteobacterial Desulfoluna MAG GLD-1 recovered in this study supported previous observations because it encoded capacity to use various fermentation products, including butyrate, lactate, and formate (Supplementary Fig. 5). The detection of more ${ }^{13} \mathrm{C}$-labeled putative SRM of the Deltaproteobacteria from protein incubations than from lipid incubations may have reflected the more diverse taxa involved in primary degradation of the proteins, e.g., through more diverse metabolic interactions. We also hypothesized that the additional nitrogen supplied by the proteins may have facilitated the growth of more diverse Deltaproteobacteria, since none of the VFAs appeared to be limiting in either protein or lipid treatments. 
In conclusion, this study provided new insights into the identities and functions of various protein- and lipiddegrading bacteria in cold marine sediments, and indicates that Psychromonas spp. are prominent and active players in the utilization of fresh detrital protein and/or lipid macromolecules. The activity of these primary hydrolysers also facilitates transfer of carbon and energy between trophic levels within the sediment microbial community. Future work could specifically examine the roles of Archaea, because our PCR primer sets only matched about $56 \%$ of Archaea in the SILVA database [43], and therefore they may have been underrepresented in our analyses. Archaea could be important, as Bathyarchaeota members in marine sediments encode the potential for protein or amino acid degradation in their genomes [28], and may be more important in deeper sediments where they often become more abundant and microbial activity is low [88].

\section{Data availability}

All sequence data sets and metagenome-assembled genomes from the DNA-SIP experiments are available under the NCBI-Genbank Bioproject PRJNA609450. DNA-SIP amplicon sequencing data sets are available in the NCBIGenbank Sequence Read Archive under BioSample accession SAMN14253696 and SRA accessions SRR11221408SRR11221561. Metagenomic sequence reads are available in the NCBI-Genbank Sequence Read Archive under BioSample accession numbers SAMN14421543SAMN14421548. Metagenome-assembled genomes are available in the NCBI-Genbank under BioSample accession numbers SAMN14421524-SAMN14421532. Annotated MAGs and genomes from the MicroScope annotation platform for key protein- and lipid-degrading organisms, and Psychrilyobacter atlanticus DSM 19335, are publicly available in the MaGe-Microscope server (https://mage. genoscope.cns.fr/). Amplicon sequencing data sets from Svalbard sediments are available under NCBI-Genbank Bioproject PRJNA623111 and the BioSample accession numbers SAMN14538997-SAMN14539076.

Acknowledgements The authors would like to thank the crew of the R/V Sanna 2013 summer sampling campaign, which was funded by the Arctic Research Centre, Aarhus University, and Kasper Kjeldsen, Hans Røy, and Marit-Solveig Seidenkranz for providing the sediment samples. We thank captain (Stig Henningsen) and first mate of MS Farm for their assistance during sampling of Svalbard sediments in 2017, as well as the Kings Bay Marine Laboratory and the AWIPEV Arctic Research Base in Ny-Ålesund for assistance and laboratory space. Furthermore, the authors want to thank Carmen Czepe from the Vienna Biocenter Core Facilities Next Generation Sequencing facility for sequencing of metagenomic libraries on the Illumina Hiseq2500 instrument. This work was financially supported by the Austrian Science Fund (P29426-B29 to KW; P25111-B22 to AL).

\section{Compliance with ethical standards}

Conflict of interest The authors declare that they have no conflict of interest.

Publisher's note Springer Nature remains neutral with regard to jurisdictional claims in published maps and institutional affiliations.

Open Access This article is licensed under a Creative Commons Attribution 4.0 International License, which permits use, sharing, adaptation, distribution and reproduction in any medium or format, as long as you give appropriate credit to the original author(s) and the source, provide a link to the Creative Commons license, and indicate if changes were made. The images or other third party material in this article are included in the article's Creative Commons license, unless indicated otherwise in a credit line to the material. If material is not included in the article's Creative Commons license and your intended use is not permitted by statutory regulation or exceeds the permitted use, you will need to obtain permission directly from the copyright holder. To view a copy of this license, visit http://creativecommons. org/licenses/by/4.0/.

\section{References}

1. Hop H, Pearson T, Hegseth EN, Kovacs KM, Wiencke C, Kwasniewski S, et al. The marine ecosystem of Kongsfjorden, Svalbard. Polar Res. 2002;21:167-208.

2. Arndt S, Jørgensen BB, LaRowe DE, Middelburg JJ, Pancost RD, Regnier P. Quantifying the degradation of organic matter in marine sediments: a review and synthesis. Earth-Sci Rev. 2013;123:53-86.

3. Dunne JP, Sarmiento JL, Gnanadesikan A. A synthesis of global particle export from the surface ocean and cycling through the ocean interior and on the seafloor. Glob Biogeochem Cycles. 2007;21:1-16.

4. Christian JR, Karl DM. Bacterial ectoenzymes in m`arine waters: activity ratios and temperature responses in three oceanographic provinces. Limnol Oceanogr. 1995;40:1042-9.

5. Fabiano M, Pusceddu A. Total and hydrolizable particulate organic matter (carbohydrates, proteins and lipids) at a coastal station in Terra Nova Bay (Ross Sea, Antarctica). Polar Biol. 1998;19:125-32.

6. Bradley JA, Amend JP, LaRowe DE. Necromass as a limited source of energy for microorganisms in marine sediments. $\mathrm{J}$ Geophys Res Biogeosci. 2018;123:577-90.

7. Wehrmann LM, Formolo MJ, Owens JD, Raiswell R, Ferdelman TG, Riedinger N, et al. Iron and manganese speciation and cycling in glacially influenced high-latitude fjord sediments (West Spitsbergen, Svalbard): evidence for a benthic recycling-transport mechanism. Geochim Cosmochim Acta. 2014;141:628-55.

8. Burdige DJ. Preservation of organic matter in marine sediments: controls, mechanisms, and an imbalance in sediment organic carbon budgets? Chem Rev. 2007;107:467-85.

9. Hedges JI, Oades JM. Comparative organic geochemistries of soils and marine sediments. Org Geochem. 1997;27:319-61.

10. McCarthy M, Pratum T, Hedges J, Benner R. Chemical composition of dissolved organic nitrogen in the ocean. Nature. 1997;390:150-4.

11. Vetter YA, Deming JW. Extracellular enzyme activity in the Arctic Northeast Water polynya. Mar Ecol Prog Ser. 1994;114:23-34.

12. Parsons TR, Stephens K, Strickland JDH. On the chemical composition of eleven species of marine phytoplankters. J Fish Res Board Can. 1961;18:1001-16. 
13. Hudson BJ, Karis IG. The lipids of the alga Spirulina. J Sci Food Agric. 1974;25:759-63.

14. Wakeham SG, Lee C, Farrington JW, Gagosian RB. Biogeochemistry of particulate organic matter in the oceans: results from sediment trap experiments. Deep Sea Res A. 1984;31:509-28

15. Harvey HR, Rodger Harvey H, Fallon RD, Patton JS. The effect of organic matter and oxygen on the degradation of bacterial membrane lipids in marine sediments. Geochim Cosmochim Acta. 1986;50:795-804.

16. Sousa DZ, Smidt H, Alves MM, Stams AJM. Ecophysiology of syntrophic communities that degrade saturated and unsaturated long-chain fatty acids. FEMS Microbiol Ecol. 2009;68:257-72.

17. Meyer-Reil L-A. Ecological aspects of enzymatic activity in marine sediments. Brock/Springer Series in Contemporary Bioscience; Springer New York New York, NY 1991. p. 84-95.

18. Beulig F, Røy H, Glombitza C, Jørgensen BB. Control on rate and pathway of anaerobic organic carbon degradation in the seabed. Proc Natl Acad Sci USA. 2018;115:367-72.

19. Arnosti C. Microbial extracellular enzymes and the marine carbon cycle. Ann Rev Mar Sci. 2011;3:401-25.

20. Arnosti C. Contrasting patterns of peptidase activities in seawater and sediments: an example from Arctic fjords of Svalbard. Mar Chem. 2015;168:151-6.

21. Muyzer G, Stams AJM. The ecology and biotechnology of sulphate-reducing bacteria. Nat Rev Microbiol. 2008;6:441-54.

22. Webster G, Watt LC, Rinna J, Fry JC, Evershed RP, Parkes RJ, et al. A comparison of stable-isotope probing of DNA and phospholipid fatty acids to study prokaryotic functional diversity in sulfate-reducing marine sediment enrichment slurries. Environ Microbiol. 2006;8:1575-89.

23. Müller AL, Pelikan C, de Rezende JR, Wasmund K, Putz M, Glombitza C, et al. Bacterial interactions during sequential degradation of cyanobacterial necromass in a sulfidic arctic marine sediment. Environ Microbiol. 2018;20:2927-40.

24. Knoblauch C, Sahm K, Jørgensen BB. Psychrophilic sulfatereducing bacteria isolated from permanently cold arctic marine sediments: description of Desulfofrigus oceanense gen. nov., sp. nov., Desulfofrigus fragile sp. nov., Desulfofaba gelida gen. nov., sp. nov., Desulfotalea psychrophila gen. nov., sp. nov. and Desulfotalea arctica sp. nov. Int J Syst Bacteriol. 1999;49: 1631-43.

25. Sahm K, Knoblauch C, Amann R. Phylogenetic affiliation and quantification of psychrophilic sulfate-reducing isolates in marine Arctic sediments. Appl Environ Microbiol. 1999;65:3976-81.

26. Na H, Lever MA, Kjeldsen KU, Schulz F, Jørgensen BB. Uncultured desulfobacteraceae and crenarchaeotal group C3 incorporate $13 \mathrm{C}$-acetate in coastal marine sediment. Environ Microbiol Rep. 2015;7:614-22.

27. Wasmund K, Mußmann M, Loy A. The life sulfuric: microbial ecology of sulfur cycling in marine sediments. Environ Microbiol Rep. 2017;9:323-44.

28. Lloyd KG, Schreiber L, Petersen DG, Kjeldsen KU, Lever MA, Steen AD, et al. Predominant archaea in marine sediments degrade detrital proteins. Nature. 2013;496:215-8.

29. Zinke LA, Glombitza C, Bird JT, Røy H, Jørgensen BB, Lloyd $\mathrm{KG}$, et al. Microbial organic matter degradation potential in Baltic Sea sediments influenced by depositional conditions and in situ geochemistry. Appl Environ Microbiol. 2018;85:e02164-18.

30. Orsi WD, Richards TA, Francis WR. Predicted microbial secretomes and their target substrates in marine sediment. Nat Microbiol. 2018;3:32-7.

31. Baker BJ, Lazar CS, Teske AP, Dick GJ. Genomic resolution of linkages in carbon, nitrogen, and sulfur cycling among widespread estuary sediment bacteria. Microbiome. 2015;3:14.
32. Boyer T, Levitus S, Garcia H, Locarnini RA, Stephens C, Antonov J. Objective analyses of annual, seasonal, and monthly temperature and salinity for the World Ocean on a 0.25 grid. Int J Climatol. 2005;25:931-45.

33. Glombitza C, Jaussi M, Røy H, Seidenkrantz M-S, Lomstein BA, Jørgensen BB. Formate, acetate, and propionate as substrates for sulfate reduction in sub-arctic sediments of Southwest Greenland. Front Microbiol. 2015;6:846.

34. Graue J, Engelen B, Cypionka H. Degradation of cyanobacterial biomass in anoxic tidal-flat sediments: a microcosm study of metabolic processes and community changes. ISME J. 2012;6:660-9.

35. Newport PJ, Nedwell DB. The mechanisms of inhibition of Desulfovibrio and Desulfotomaculum species by selenate and molybdate. J Appl Bacteriol. 1988;65:419-23.

36. Danovaro R, Dell'Anno A, Fabiano M. Bioavailability of organic matter in the sediments of the Porcupine Abyssal Plain, northeastern Atlantic. Mar Ecol Prog Ser. 2001;220:25-32.

37. Pusceddu A, Dell'Anno A, Fabiano M, Danovaro R. Quantity and bioavailability of sediment organic matter as signatures of benthic trophic status. Mar Ecol Prog Ser. 2009;375:41-52.

38. Glombitza C, Pedersen J, Røy H, Jørgensen BB. Direct analysis of volatile fatty acids in marine sediment porewater by twodimensional ion chromatography-mass spectrometry. Limnol Oceanogr Methods. 2014;12:455-68.

39. Dumont MG, Radajewski SM, Miguez CB, McDonald IR, Murrell JC. Identification of a complete methane monooxygenase operon from soil by combining stable isotope probing and metagenomic analysis. Environ Microbiol. 2006;8:1240-50.

40. Neufeld JD, Vohra J, Dumont MG, Lueders T, Manefield M, Friedrich MW, et al. DNA stable-isotope probing. Nat Protoc. 2007;2:860-6.

41. Pelikan C, Herbold CW, Hausmann B, Müller AL, Pester M, Loy A. Diversity analysis of sulfite- and sulfate-reducing microorganisms by multiplex dsrA and dsrB amplicon sequencing using new primers and mock community-optimized bioinformatics. Environ Microbiol. 2016;18:2994-3009.

42. Herbold CW, Pelikan C, Kuzyk O, Hausmann B, Angel R, Berry $\mathrm{D}$, et al. A flexible and economical barcoding approach for highly multiplexed amplicon sequencing of diverse target genes. Front Microbiol. 2016;6:731.

43. Quast C, Pruesse E, Yilmaz P, Gerken J, Schweer T, Yarza P, et al. The SILVA ribosomal RNA gene database project: improved data processing and web-based tools. Nucleic Acids Res. 2013;41:D590-6.

44. Tikhonov M, Leach RW, Wingreen NS. Interpreting 16S metagenomic data without clustering to achieve sub-OTU resolution. ISME J. 2015;9:68-80.

45. Love MI, Huber W, Anders S. Moderated estimation of fold change and dispersion for RNA-seq data with DESeq2. Genome Biol. 2014;15:550.

46. Orsi WD, Smith JM, Liu S, Liu Z, Sakamoto CM, Wilken S, et al. Diverse, uncultivated bacteria and archaea underlying the cycling of dissolved protein in the ocean. ISME J. 2016;10:2158-73.

47. Lagkouvardos I, Joseph D, Kapfhammer M, Giritli S, Horn M, Haller D, et al. IMNGS: a comprehensive open resource of processed 16S rRNA microbial profiles for ecology and diversity studies. Sci Rep. 2016;6:33721.

48. Peng Y, Leung HCM, Yiu SM, Chin FYL. IDBA-UD: a de novo assembler for single-cell and metagenomic sequencing data with highly uneven depth. Bioinformatics. 2012;28:1420-8.

49. Bankevich A, Nurk S, Antipov D, Gurevich AA, Dvorkin M, Kulikov AS, et al. SPAdes: a new genome assembly algorithm and its applications to single-cell sequencing. J Comput Biol. 2012;19:455-77. 
50. Li H, Durbin R. Fast and accurate short read alignment with Burrows-Wheeler transform. Bioinformatics. 2009;25:1754-60.

51. Li H, Handsaker B, Wysoker A, Fennell T, Ruan J, Homer N, et al. The sequence alignment/map format and SAMtools. Bioinformatics. 2009;25:2078-9.

52. Kang DD, Froula J, Egan R, Wang Z. MetaBAT, an efficient tool for accurately reconstructing single genomes from complex microbial communities. PeerJ. 2015;3:e1165.

53. Wu Y-W, Simmons BA, Singer SW. MaxBin 2.0: an automated binning algorithm to recover genomes from multiple metagenomic datasets. Bioinformatics. 2016;32:605-7.

54. Alneberg J, Bjarnason BS, de Bruijn I, Schirmer M, Quick J, Ijaz UZ, et al. Binning metagenomic contigs by coverage and composition. Nat Methods. 2014;11:1144-6.

55. Sieber CMK, Probst AJ, Sharrar A, Thomas BC, Hess M, Tringe $\mathrm{SG}$, et al. Recovery of genomes from metagenomes via a dereplication, aggregation and scoring strategy. Nat Microbiol. 2018;3:836-43.

56. Olm MR, Brown CT, Brooks B, Banfield JF. dRep: a tool for fast and accurate genomic comparisons that enables improved genome recovery from metagenomes through de-replication. ISME J. 2017;11:2864-8.

57. Parks DH, Imelfort M, Skennerton CT, Hugenholtz P, Tyson GW. CheckM: assessing the quality of microbial genomes recovered from isolates, single cells, and metagenomes. Genome Res. 2015;25:1043-55.

58. Parks DH, Chuvochina M, Waite DW, Rinke C, Skarshewski A, Chaumeil P-A, et al. A standardized bacterial taxonomy based on genome phylogeny substantially revises the tree of life. Nat Biotechnol. 2018;36:996-1004.

59. Chaumeil PA, Mussig AJ, Hugenholtz P, Parks DH. GTDB-Tk: a toolkit to classify genomes with the Genome Taxonomy Database. Bioinformatics. 2019 Nov 15:btz848. https://doi.org/10.1093/ bioinformatics/btz848. Epub ahead of print. PMID: 31730192.

60. Nguyen L-T, Schmidt HA, von Haeseler A, Minh BQ. IQ-TREE: a fast and effective stochastic algorithm for estimating maximumlikelihood phylogenies. Mol Biol Evol. 2015;32:268-74.

61. Minh BQ, Nguyen MAT, von Haeseler A. Ultrafast approximation for phylogenetic bootstrap. Mol Biol Evol. 2013;30:1188-95.

62. Letunic I, Bork P. Interactive Tree Of Life (iTOL): an online tool for phylogenetic tree display and annotation. Bioinformatics. 2007;23:127-8.

63. Jain C, Rodriguez-R LM, Phillippy AM, Konstantinidis KT, Aluru S. High throughput ANI analysis of $90 \mathrm{~K}$ prokaryotic genomes reveals clear species boundaries. Nat Commun. 2018;9:5114.

64. Vallenet D, Calteau A, Cruveiller S, Gachet M, Lajus A, Josso A, et al. MicroScope in 2017: an expanding and evolving integrated resource for community expertise of microbial genomes. Nucleic Acids Res. 2017;45:D517-28.

65. Aziz RK, Bartels D, Best AA, DeJongh M, Disz T, Edwards RA, et al. The RAST server: rapid annotations using subsystems technology. BMC Genomics. 2008;9:75.

66. Buchfink B, Xie C, Huson DH. Fast and sensitive protein alignment using DIAMOND. Nat Methods. 2015;12:59-60.

67. Jones P, Binns D, Chang H-Y, Fraser M, Li W, McAnulla C, et al. InterProScan 5: genome-scale protein function classification. Bioinformatics. 2014;30:1236-40.

68. Finn RD, Bateman A, Clements J, Coggill P, Eberhardt RY, Eddy SR, et al. Pfam: the protein families database. Nucleic Acids Res. 2013;42:D222-30.

69. Haft DH, Selengut JD, White O. The TIGRFAMs database of protein families. Nucleic Acids Res. 2003;31:371-3.

70. UniProt Consortium. UniProt: the universal protein knowledgebase. Nucleic Acids Res. 2018;46:2699.
71. Kall L, Krogh A, Sonnhammer ELL. Advantages of combined transmembrane topology and signal peptide prediction-the Phobius web server. Nucleic Acids Res. 2007;35:W429-32.

72. Yu NY, Wagner JR, Laird MR, Melli G, Rey S, Lo R, et al. PSORTb 3.0: improved protein subcellular localization prediction with refined localization subcategories and predictive capabilities for all prokaryotes. Bioinformatics. 2010;26:1608-15.

73. Rawlings ND. MEROPS: the peptidase database. Nucleic Acids Res. 2000;28:323-5.

74. Lenfant N, Hotelier T, Velluet E, Bourne Y, Marchot P, Chatonnet A. ESTHER, the database of the $\alpha / \beta$-hydrolase fold superfamily of proteins: tools to explore diversity of functions. Nucleic Acids Res. 2013;41:D423-9.

75. Lombard V, Golaconda Ramulu H, Drula E, Coutinho PM, Henrissat B. The carbohydrate-active enzymes database (CAZy) in 2013. Nucleic Acids Res. 2014;42:D490-95. https://doi.org/10. 1093/nar/gkt1178.

76. Altschul SF, Madden TL, Schäffer AA, Zhang J, Zhang Z, Miller W, et al. Gapped BLAST and PSI-BLAST: a new generation of protein database search programs. Nucleic Acids Res. 1997;25:3389-402.

77. Steen AD, Kevorkian RT, Bird JT, Dombrowski N, Baker BJ, Hagen SM, et al. Kinetics and identities of extracellular peptidases in subsurface sediments of the White Oak River Estuary, North Carolina. Appl Environ Microbiol. 2019;85:e0102-19.

78. Pruesse E, Peplies J, Glöckner FO. SINA: accurate highthroughput multiple sequence alignment of ribosomal RNA genes. Bioinformatics. 2012;28:1823-9.

79. Price MN, Dehal PS, Arkin AP. FastTree 2-approximately maximum-likelihood trees for large alignments. PLoS ONE. 2010;5:e9490.

80. Berger SA, Krompass D, Stamatakis A. Performance, accuracy, and Web server for evolutionary placement of short sequence reads under maximum likelihood. Syst Biol. 2011;60:291-302.

81. Stamatakis A. RAxML version 8: a tool for phylogenetic analysis and post-analysis of large phylogenies. Bioinformatics. 2014;30: 1312-3.

82. Zhao J-S, Manno D, Hawari J. Psychrilyobacter atlanticus gen. nov., sp. nov., a marine member of the phylum Fusobacteria that produces $\mathrm{H}_{2}$ and degrades nitramine explosives under low temperature conditions. Int $\mathrm{J}$ Syst Evol Microbiol. 2009;59:491-7.

83. Hedges JI, Oades JM. Comparative organic geochemistries of soils and marine sediments. Org Geochem. 1997;27:319-61.

84. Wakeham SG, Canuel EA. Degradation and preservation of organic matter in marine sediments. In: The handbook of environmental chemistry; Springer Berlin Heidelberg Berlin, Heidelberg 2006. p. 295-321.

85. Bienhold C, Boetius A, Ramette A. The energy-diversity relationship of complex bacterial communities in Arctic deep-sea sediments. ISME J. 2011;6:724-32.

86. Finke N, Vandieken V, Jørgensen BB. Acetate, lactate, propionate, and isobutyrate as electron donors for iron and sulfate reduction in Arctic marine sediments, Svalbard. FEMS Microbiol Ecol. 2007;59:10-22.

87. Glombitza C, Egger M, Røy H, Jørgensen BB. Controls on volatile fatty acid concentrations in marine sediments (Baltic Sea). Geochim Cosmochim Acta. 2019;258:226-41.

88. Kubo K, Lloyd KG, F Biddle J, Amann R, Teske A, Knittel K. Archaea of the Miscellaneous Crenarchaeotal Group are abundant, diverse and widespread in marine sediments. ISME J. 2012;6:1949-65.

89. Katoh K, Misawa K, Kuma K, Miyata T. MAFFT: a novel method for rapid multiple sequence alignment based on fast Fourier transform. Nucleic Acids Res. 2002;30:3059-66. 